\title{
JUURNAL.RU
}

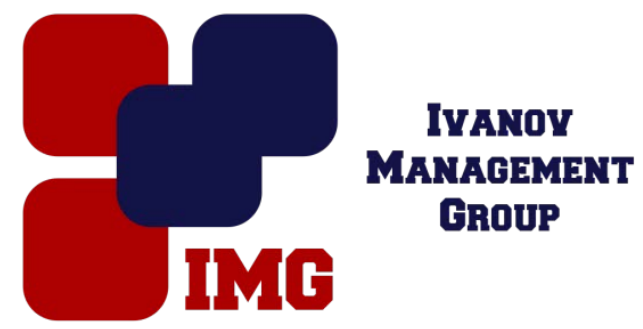

Цымбаленко Е.Г. Уразовская средняя общеобразовательная школа №2

doi: 10.18411/lj-31-01-2017-3-05

idsp 000001:lj-31-01-2017-3-05

\section{Здоровье сберегающие технологии на уроках биологии в современной школе}

\section{Аннотация}

Проблема здоровья детей на данный момент очень актуальна. Можно сказать, что именно учитель в состоянии сделать для здоровья современного ученика больше, чем доктор. Учитель должен работать так, чтобы обучение детей в школе не наносило ущерба их здоровью, не снижало уровня мотивации обучения, и прежде всего учебно-познавательных мотивов ученика.

Поэтому, на уроках я использую здоровьесберегающие технологии, предполагающие совокупность педагогических, психологических и медицинских воздействий, направленных на защиту и обеспечение здоровья учащихся и формирование ценного отношения к нему.

Ключевые слова: здоровье, здоровьесберегающие технологии, здоровый образ жизни, динамические паузы, физкультминутки

Мой Боже, в некий час Помьсслил я: иарь строит свой двореи, Чтоб в нём жилище обрести, Но можно ль краше храм найти, Чем человек? Дж. Герберт

Здоровье, здоровый образ жизни, здоровое сознание - все эти понятия мы слышим по телевидению, радио, читаем в прессе, книгах. Казалось бы, всех людей, в данный момент, интересует эта тема, все всё об этом хорошо знают, все стараются придерживаться ЗОЖ. Неужели скоро проблема со здоровьем сама по себе исчезнет...У всех живущих будет «здоровое сознание» и все будут вести здоровый образ жизни. Почему же тогда, с каждым годом, здоровых людей становится в разы меньше, а выпускники школ, практически все имеют хронические заболевания всех органов и систем.

Не надо доказывать значение здоровья ребёнка для его физического и душевного развития. Для нас, взрослых, здоровье детей «...является ни с чем 
несравнимым сокровищем. Здоровье является необходимым условием для полноты жизни, радости существования, без которых невозможен расцвет личности...» [1]

Мне, как учителю биологии, близка эта тема - тема здоровья. Передо мной всегда вставал вопрос - как избавить ребят от недостатка двигательной активности, неправильного питания, несоблюдения гигиенических требований и отсутствием элементарных знаний о том, как стать здоровым. Не случайно, «красной нитью» деятельности современной школы является сохранение здоровья подрастающего поколения.

В нашей школе, уже несколько лет, ведётся экспериментальная работа «Формирование здоровьесберегающей среды для повышения успеваемости учащихся и качества образовательного процесса». Для себя, как для учителя биологии, я поставила цель - обеспечение учащимся возможности сохранения здоровья.

Одной из проблем, стоящей в нашем обществе является гиподинамия. Разговаривая с ребятами, всё больше в этом убеждаюсь. Ученики, просидев на уроках 6-8 часов, отправляются домой к своим компьютерам. И так изо дня в день. Уменьшается не только двигательная активность, но и время, проведенное на свежем воздухе.

В свою практику я активно внедряю физкультминутки, которые предусматривают смену динамических поз. Например - если ребята выполняли работу в тетради, то провожу упражнения для расслабления кистей рук, массаж пальцев и разгрузки позвоночника, гимнастику для органов зрения. Движения я подбираю таким образом, чтобы они были разнообразными и проводились для утомлённых групп мышц, то есть зависели от специфики урока. На каждом уроке дети должны быть в движении. Это я достигаю такими приёмами, как работа в группах, работа у доски, тестирование при помощи ПК, работа в минилаборатории, сюжетно-ролевыми играми.

При изучении анатомии человека, мы с восьмиклассниками, обязательно рассматриваем все темы применительно к своему организму. При изучении пищеварительной системы ребята знакомятся с энергетической ценностью и составом пищевых продуктов, с необходимостью сбалансированного питания с культурой приёма пищи и соблюдению гигиенических норм. Обучающиеся не только узнают о здоровом питании, но и самостоятельно составляют меню на каждый день. Ученики, проводя опыты, доказывают пагубность жевательной резинки, fast food и сладких газированных напитков. При изучении дыхательной системы, ребята учатся правильно дышать и выполнять тренировку дыхания, которая не только развивает органы дыхания, но и способствует повышению культуры общения.

При изучении тем:

- «Опорно-двигательная система», последний урок отвожу на практическое занятие по теме «Осанка. Предупреждение плоскостопия»;

- «Сердечно-сосудистая система» провожу лабораторные занятия: «Изменение в тканях при перетяжках, затрудняющих кровообращение», «Реакция ССС на дозированную нагрузку»; 
- «Дыхательная система» провожу учебное занятие «Функциональные возможности дыхательной системы как показатель здоровья. Болезни и травмы органов дыхания их профилактика и приемы реанимации»;

- «Пищеварительная система» провожу учебные занятия «Гигиена органов пищеварения. Предупреждение ЖК инфекций» и «Установление зависимости между дозированной нагрузкой и уровнем энергетического обмена»;

Для 9-11 классов разработала занятия по формированию ЗОЖ и профилактические мероприятия, которые должны проводиться постоянно каждым человеком. Провожу внеклассные мероприятия по темам: «Суд над вредными привычками», круглый стол «Спид - чума 21 века», КВН «Что такое ЗОЖ?». На уроках биологии при изучении темы «Ген - носитель наследственной информации» обучающиеся узнают о генетических наследственных заболеваниях, генных мутациях, причинах и профилактике этих болезней.

Восьмиклассникам интересны занятия по учебному элективному курсу «Экология человека». Ребятам-подросткам вдвойне полезнее информация о строении и функциях своего организма, о том, что связано с рисками для здоровья (курение, употребление алкоголя, ранние сексуальные связи). Именно в этом возрасте необходимо сформировать представления и о негативных последствиях «взрослой» жизни с одной стороны, и о способах демонстрации взрослости, направленных на укрепление собственного здоровья с другой. Эти знания должны стать основой для формирования культуры здоровья. [2] Эта работа должна проводиться совместно с родителями.

Если мы не научим детей с самого детства ценить, беречь и укреплять своё здоровье, если мы не будем личным примером демонстрировать здоровый образ жизни, то только в этом случае можно с уверенностью сказать, что будущие поколения будут более здоровы и развиты не только личностно, интеллектуально, духовно, но и физически.

Наша же задача, как педагогов -воспитателей - обеспечить выпускнику школы высокий уровень здоровья, вооружить его необходимым багажом знаний, умений, навыков, необходимых для ведения здорового образа жизни, и воспитав у него культуру здоровья. И тогда, аттестат о среднем образовании, будет действительно путёвкой в счастливую самостоятельную жизнь и молодой человек будет не только заботиться о своём здоровье, но и бережно относиться к здоровью других людей. Н. Чернышевский сказал: «Прекрасное и красивое в человеке немыслимо без представления о гармоническом развитии организма и здоровья». 


\section{Литература}

1. Аркин Е.А. «Родителям о воспитании» Государственное учебно-педагогическое издательство Министерства просвещения РСФСР Москва 1957, С.30-32

2. Биология в школе Научно-методический журнал №1 2008 «О формировании культуры здоровья у подростков» Макеева А.Г., С.3-8 